\title{
ARTYKULY
}

\author{
Piotr Werner
}

\section{CZY GIS PODNOSI RANGE DYSCYPLIN GEOGRAFICZNYCH? ZNACZENIE GIS I GISCIENCE DLA GEOGRAFII}

\begin{abstract}
Zarys treści: Geografowie postrzegają technologie informacyjne i komunikacyjne, w tym oprogramowanie GIS, jako element nieuchronnych przemian w geografii. Część uważa, że są instrumentami pomocniczymi geografii, część zauważa „cyfrowy zwrot” (digital turn), który odnawia zainteresowanie i związki z takimi dziedzinami, jak computational social sciences oraz data-driven geography w celu uzyskania głębszego wglądu w badania ilościowe, w skali czasowej, wielorozdzielcze i wieloskalowe. Współcześnie różnorodność cyfrowych urządzeń, platform, aplikacji i usług jest nieodłącznym, normalnym i oczekiwanym elementem codziennego życia, a technologie cyfrowe są również standardem medialnym generowania i analizy wiedzy w badaniach jakościowych. W miarę postępu, komercjalizacji i popularyzacji technologii geoprzestrzennych, one same przyczyniają się do rozwoju ontologii i epistemologii przestrzennych. Analiza semantyczna artykułów opublikowanych w najważniejszych czasopismach naukowych dedykowanych różnym dyscyplinom geografii (w latach 2014-2018) dowodzi, że w geograficznym dyskursie naukowym najbardziej aktywne jawią się czasopisma geograficzne podejmujące tematykę interdyscyplinarną, metodologiczną lub z zakresu geografii stosowanej.
\end{abstract}

Słowa kluczowe: technologie informacyjne i komunikacyjne, GIS, geografia, cyfryzacja, geograficzny dyskurs naukowy.

„Geografowie długo dyskutowali o zaletach intelektualnych systemów informacji geograficznej (GIS) oraz ich znaczeniu dla dyscypliny. Nadal jednak pozycja GIS w geografii jest kontestowana, chociaż niektóre kwestie [problemy teoretyczne i praktyczne - przyp. aut.] zostały rozwiązane. Współcześnie obserwowane trendy dowodzą raczej zbliżenia do informatyki, a GIS znalazł uznanie i jest nauczany i wykorzystywany w wielu dziedzinach poza geografią. Jeżeli kiedykolwiek w przeszłości można było uznać, że GIS jest częścią geografii, to geografia przegrała tą bitwę. [...] Współcześnie rysuje się [...] różnica między GIS i GIScience (geomatyką, geoinformatyką) oraz zmienia się ich znaczenie 
dla geografii, jak również znaczenie dyscyplin geograficznych dla GIScience. W momencie, kiedy wkraczamy w erę wielkich zbiorów danych (big data) i sztucznej inteligencji, ta perspektywa prawdopodobnie zyska na znaczeniu".

"Geographers have long argued about the intellectual merits of geographic information systems, and about their relevance to the discipline. While some of these issues have been resolved, the place of GIS in geography is still contested. Recent trends have perhaps drawn GIS closer to computer science, and GIS is today being taught in many disciplines besides geography. If there ever was a case that geography was where GIS belonged, that battle is long since lost. I present a personal and contemporary view of the difference between GIS and GIScience, the importance of geography to GIScience, and the importance of GIScience to geography. This perspective is likely to grow in significance as we move into the age of big data and artificial intelligence".

Michael F. Goodchild, 2018, Geography and GISCIENCE, [Keynote summary], IGU Regional Conference, Quebec, 9/08/2018.

\section{Wprowadzenie}

W ciągu prawie 50 lat rozwoju GIS (przyjmując umownie za rok początkowy 1970 i pojawienie się CGIS autorstwa Rogera Tomlinsona) można wyróżnić kilka faz rozwoju (Werner 2013): począwszy od okresu pionierskiego (1970-1980), poprzez etapy rozwoju instytucjonalnego, komercyjnego i publicznego, z których każda, następując po sobie, wcale nie straciły swojego impetu i innowacyjności - algorytmizacji procedur i zakresu zastosowań (aplikacji). Można się spierać o dokładniejsze wyznaczenie dat, ale większość autorów jest zgodna co do wskazanych wątków rozwoju GIS (Yuan 2015): fazy pionierskiej, fazy wsparcia państwowego rozwoju GIS (national drivers), dominacji firm komercyjnych (commercial dominance), dominacji użytkowników (user dominance), które przeplatając się tworzą wspólnie fundamenty kultury technicznej społeczeństwa (geo)informacyjnego. Ostatnim, często wskazywanym trendem jest pojawienie się dyscypliny nazwanej przez M.F. Goodchilda początku lat 90. GIScience (2018), niekiedy geocomputation, (Onsrud, Kuhn 2016), a w innych krajach geomatyką lub geoinformatyką (geomatics, geoinformatics).

Niewątpliwie wprowadzenie GIS do praktyki i nauki geografii doprowadziło do wszczęcia na nowo dyskusji w geografii dotyczącej formalnych i faktycznych podstaw funkcjonowania i społecznej percepcji dużej liczby (sub)dyscyplin geograficznych. Uprawianie i stosowanie geografii wiąże się z identyfikacją problemu geograficznego, definicją jego skali badania (odpowiedniej perspektywy), zasięgu przestrzennego, ram czasowych i w końcu doborem tematyki: ogólnej, regionalnej, fizycznej lub społeczno-geograficznej, co podkreślają nawet doświadczeni geografowie (ryc. 1) (Holt-Jensen 2018: 1981). 


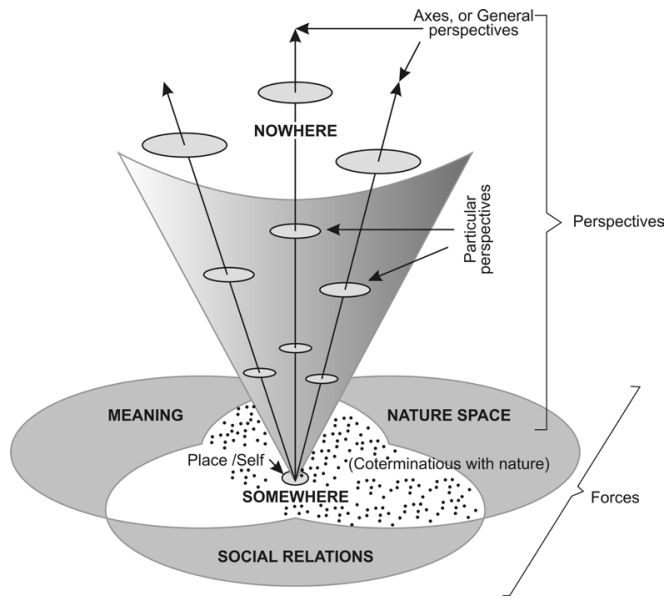

Ryc. 1. Perspektywa, skala i tematyka badań geograficznych

Źródło: The relational geographic framework (Holt-Jensen 2018).

Znaczenie ma także percepcja wyników badań geograficznych, ich epistemologiczna płaszczyzna rozumienia przez odbiorców (użytkowników) lub innych geografów (ryc. 2) (Holt-Jensen 2018), w kontekście określonego podejścia obowiązującego paradygmatu naukowego: scjentystycznego (właściwego dla nauk STEM $^{1}$ ) lub antyscjentystycznego (właściwego dla nauk społecznych i humanistycznych).

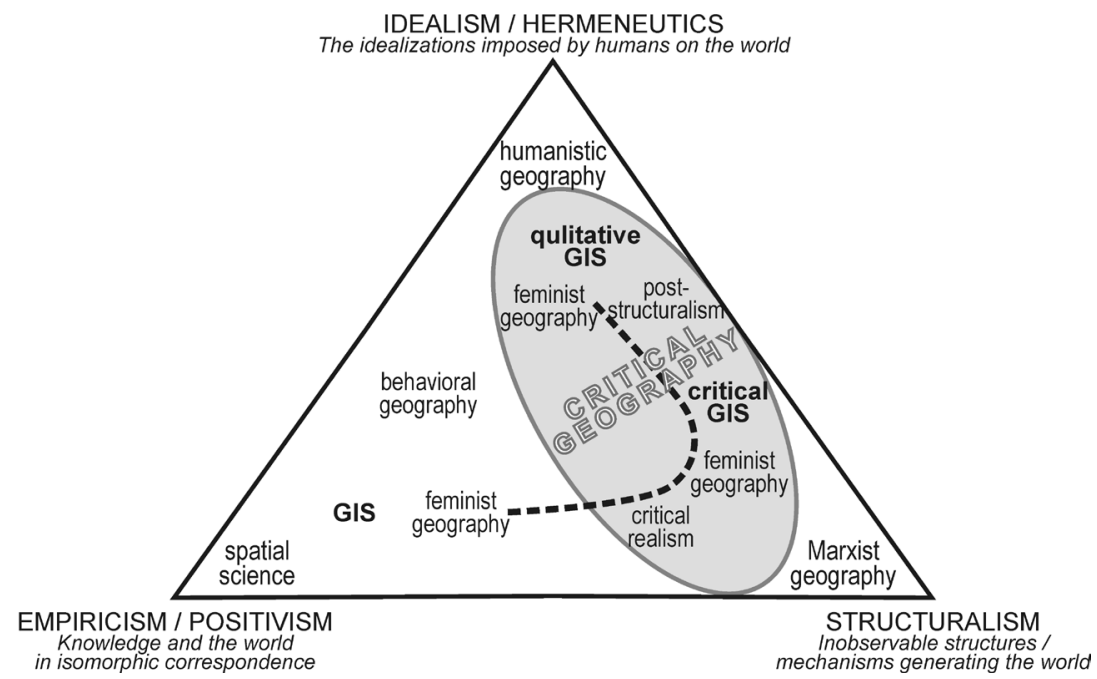

Ryc. 2. Trójkąt epistemologiczny: geografia i GIS

Źródło: A. Holt-Jensen (2018), za: E. Sheppard (2015).

\footnotetext{
${ }^{1}$ STEM - Science, Technology, Engineering and Mathematics.
} 
Geografia jako dyscyplina, której racją bytu jest wyjaśnienie zróżnicowania i różnorodności (McDowell 2008), najczęściej wykorzystuje różne aplikacje (programy) GIS, stosując je na podobieństwo metod matematyki i statystyki (analogia do rewolucji ilościowej w geografii w latach 70 . XX wieku nasuwa się sama). Dychotomia geografii jako dyscypliny objawia się też w przyjętej przez OECD klasyfikacji dziedzin nauki i dyscyplin naukowych, gdzie geografia fizyczna zaliczona została do dziedzin nauk o Ziemi i środowisku, a geografia społeczna, gospodarcza, kulturowa, transportu, demografia i miast (urbanistyka) do dziedzin nauk społecznych. Znalazło to odzwierciedlenie w aktualnym rozporządzeniu MNiSW dotyczącym klasyfikacji dziedzin i dyscyplin (Rozporządzenie Ministra Nauki i Szkolnictwa Wyższego z dnia 20 września 2018 roku w sprawie dziedzin nauki $i$ dyscyplin naukowych oraz dyscyplin artystycznych) $)^{2}$, gdzie geografię społeczno-ekonomiczną i gospodarkę przestrzenną zaliczono do dziedziny nauk społecznych.

Równocześnie jednak nadal część geografów postrzega technologie informacyjne i komunikacyjne, w tym oprogramowanie GIS, jako element nieuchronnych przemian w geografii: „Twierdzimy, że geografia znajduje się w samym środku cyfrowego zwrotu (digital turn). [...] Współczesny sposób generowania, przetwarzania, przechowywania, analizy i współdzielenia danych, tworzenia i obiegu tekstów, wizualizacji, map, analizy, przekazu idei, wideo, podkastów i prezentacji, współdzielenia informacji, angażowania się w debaty publiczne za pośrednictwem list mailowych, serwisów społecznościowych i mediów głównego nurtu są całkowicie zależne od technologii obliczeniowych" (Ash, Kitchin, Leszczynski 2018). Współczesna geografia w dobie cyfrowego zwrotu posługuje się wielkimi zbiorami danych (big data), metodami sztucznej inteligencji - uczenia maszynowego (data mining, pattern recognition, geowizualizacjami, statystyką przestrzenną, optymalizacją i symulacjami przestrzennymi), które z kolei odnowiły zainteresowanie i związki z dziedzinami: computational social sciences (Lazer i in. 2009) oraz data-driven geography (Miller, Goodchild 2015), w celu uzyskania głębszego wglądu w badania ilościowe, w skali czasowej, wielorozdzielcze i wieloskalowe (Kitchin 2014). Jednak przejawiała się też fala krytyki, która dotykała roli, statusu i zakresu wykorzystania GIS w geografii. Była i jest ona też elementem szerszego spojrzenia na rolę technologii informacyjnych i komunikacyjnych (ICT) w rozwoju społeczeństwa. Podnoszono głównie, że chociaż projekty i wdrażanie ICT mają ogromny pozytywny potencjał, to zbyt często miały jednak negatywne skutki dla uboższych i zmarginalizowanych grup społecznych, niekiedy oczekiwane, a niekiedy nieoczekiwane. Ta obserwacja znajduje potwierdzenie także w (obecnie coraz częściej wypowiadanej) tezie, że w ciągu ostatnich dwudziestu lat postęp technologii informacyjnych i komunikacyjnych

\footnotetext{
${ }^{2}$ Dz.U., 2018, poz. 1818.
} 
(ICT) raczej wzmógł nierówności rozwojowe na świecie. A jeśli rozwój jest postrzegany jako względna różnica pomiędzy ludźmi i społeczeństwami, to postęp w dziedzinie ICT miał przytłaczający, negatywny wpływ na rozwój (Unwin 2017). Ta krytyczna refleksja na temat ICT i rozwoju społeczno-gospodarczego znalazła także swoje odzwierciedlenie w geografii w kontekście wykorzystania GIS i kartografii. Krytyka GIS w geografii była formułowana przede wszystkim z pozycji ,critical cartography'. Efektem był ,critical GIS'. Chodziło o to, czyja wiedza będzie wykorzystywana w GIS, przez kogo i dla kogo będzie upowszechniana (co oznaczało odrzucenie neutralności metodologicznej technologii, tzw. niepożądanej epistemologii nauki). Klasyczny jest (przytoczony w referacie plenarnym M.F. Goodchilda (2018), na regionalnej konferencji Międzynarodowej Unii Geograficznej w Quebec w Kanadzie) przykład wyników analiz geograficznych zależnie od skali badania i problemu stref (grupowania), wykorzystując problem zmiennej jednostki odniesienia (ang. modifiable areal unit problem, MAUP).

Jednak włączenie geografii w proces wytwarzania ,cyfrowej wiedzy’ nie ogranicza się wyłącznie do GIS.

\section{Metody badań}

Współcześnie różnorodność cyfrowych urządzeń, platform, aplikacji i usług jest nieodłącznym, normalnym i oczekiwanym elementem codziennego życia (Ash, Kitchin, Leszczynski 2018). Technologie cyfrowe są również standardem medialnym generowania i analizy wiedzy w badaniach jakościowych; wdrażane są metody cyfrowe przechwytywania i analiz jakościowych i nieustrukturyzowanych danych (Rogers 2015). Wykorzystuje się kluczowe techniki, takie jak mapowanie i geowizualizacje, aby ujawnić wzorce i procesy przestrzenne. Technologia cyfrowa zmieniła kształt prowadzonych badań geograficznych, stając się centrum różnych subdyscyplin geografii. W miarę postępu, komercjalizacji i popularyzacji technologii geolokalizacji (technologii geoprzestrzennych), one same przyczyniają się do rozwoju ontologii i epistemologii przestrzennych. Jednak geografowie $\mathrm{z}$ dystansem podchodzą do adopcji tych technologii, niełatwo otwierając się na cyfrowe metodologie budujące nową, cyfrową ontologię i epistemologię geografii (Ash, Kitchin, Leszczynski 2018).

Jednym ze sposobów na ocenę znaczenia GIS i GIScience (geomatyki, geoinformatyki) dla geografii jest analiza artykułów opublikowanych w najważniejszych czasopismach naukowych dedykowanych różnym dyscyplinom geografii (w latach 2014-2018). Analizowano tytuły, słowa kluczowe i uzyskane streszczenia czasopism w jęz. angielskim (wg stanu na miesiąc kwiecień 2018) wykorzystując różne aplikacje (m.in. Zotero, Mendeley, Publish or Perish, VOSviewer, Google Scholar) i dzieląc je na grupy poświęcone tematycznie w zakresie: 
- geografii ogólnej,

- geografii fizycznej (oraz pokrewnej tematyki),

- geografii społeczno-ekonomicznej (oraz pokrewnej tematyki),

- geografii stosowanej i kartografii (związanych z geografią).

W kategoryzacji czasopism posłużono się klasyfikacją wzorowaną na liście najważniejszych naukowych czasopism geograficznych, wyodrębniając również w ramach poszczególnych kategorii czasopisma dedykowane (geografii) i interdyscyplinarne (Rosenberg 2017). Wizualizację przedstawiono w postaci wykresów tree maps (uwzględniając klasyfikację, wyodrębniając w miarę możliwości lokalizację wydawcy), ujawniając także liczbę artykułów i cytowań (tylko dla wartości najwyższych, gdzie możliwe było ich czytelne przedstawienie na wykresach). Następnie poddano (półautomatycznej) analizie kontekstowej zebrane tytuły, streszczenia i słowa kluczowe, odrzucając te artykuły, które nie miały powiązań z terminem GIS.

\section{Realizacja badań}

Zestawienie ilościowe liczby i cytowań artykułów na tematy powiązane z GIS w zakresie geografii ogólnej dotyczyło czasopism ujawnionych na ryc. 3 .

$\mathrm{Na}$ podstawie analizy słów kluczowych i streszczeń próbowano ujawnić powiązania tematyczne artykułów z terminem GIS, dokonując analizy kontekstowej i wybierając najczęściej pojawiające się pojęcia dla czasopism amerykańskich - ryc. 4.

Analogiczną procedurę zastosowano dla wybranych czasopism z zakresu geografii fizycznej w języku angielskim (ryc. 5, 6) oraz geografii społeczno-ekonomicznej (ryc. 7, 8) także w języku angielskim. Analizę kontekstową artykułów w zakresie geografii fizycznej podzielono grupując czasopisma jako dedykowane geografii fizycznej (core journals) i interdyscyplinarne o tematyce związanej z geografią fizyczną (physical geography related). Podobnie dla geografii społeczno-ekonomicznej. Zdecydowanie w zakresie zastosowań GIS prym wiodą dyscypliny związane z geografią fizyczną, następnie o tematyce ogólnej i związane z geografią społeczno-ekonomiczną. W tematyce GIS dominują czasopisma interdyscyplinarne, publikujące więcej artykułów o większej liczbie cytowań niż te, które dedykowane są geografii. W analizie osobno wyodrębniono grupę czasopism związanych z geografią stosowaną i kartografią (w języku angielskim, ryc. 9,10$)$. 


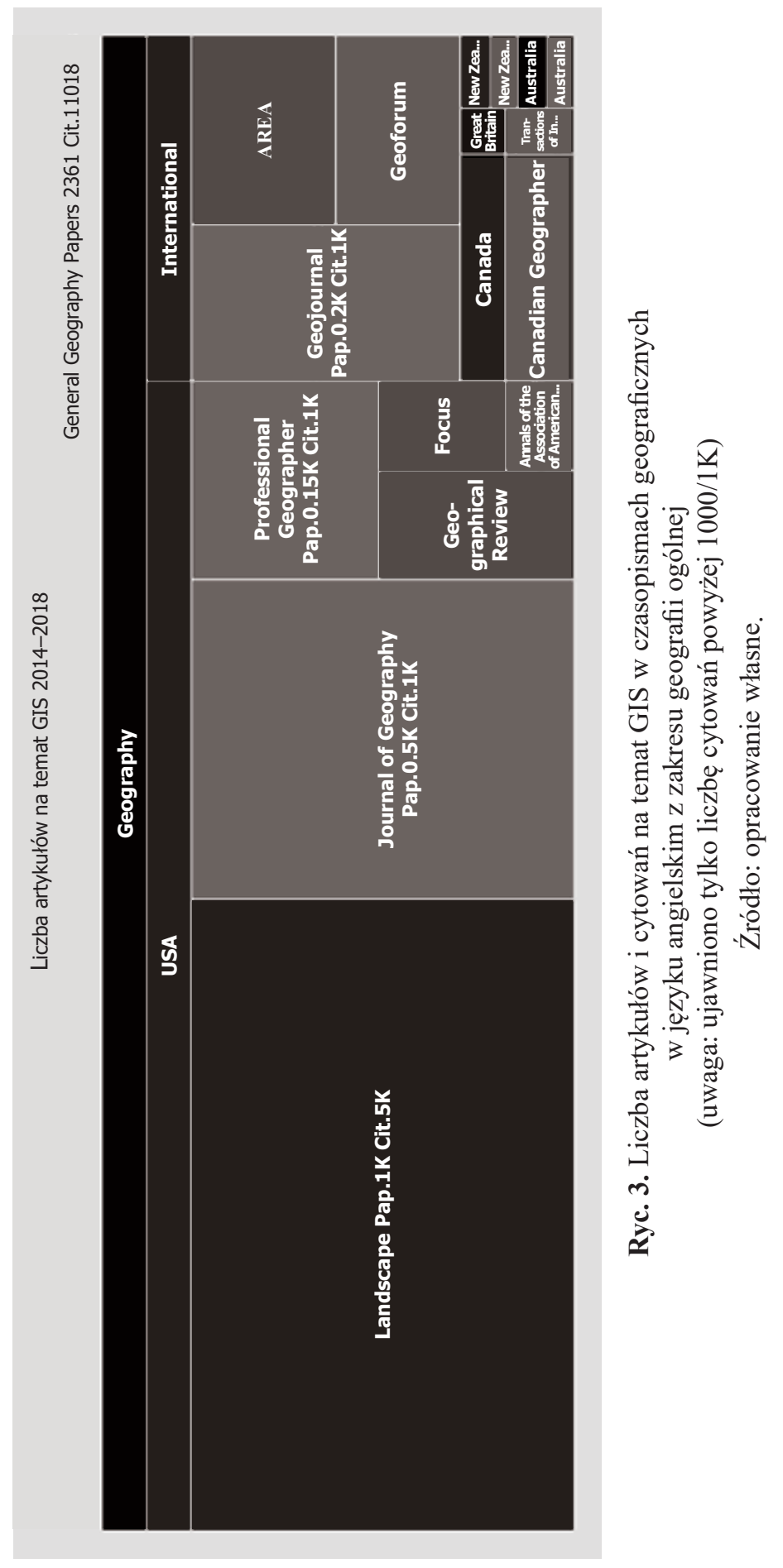




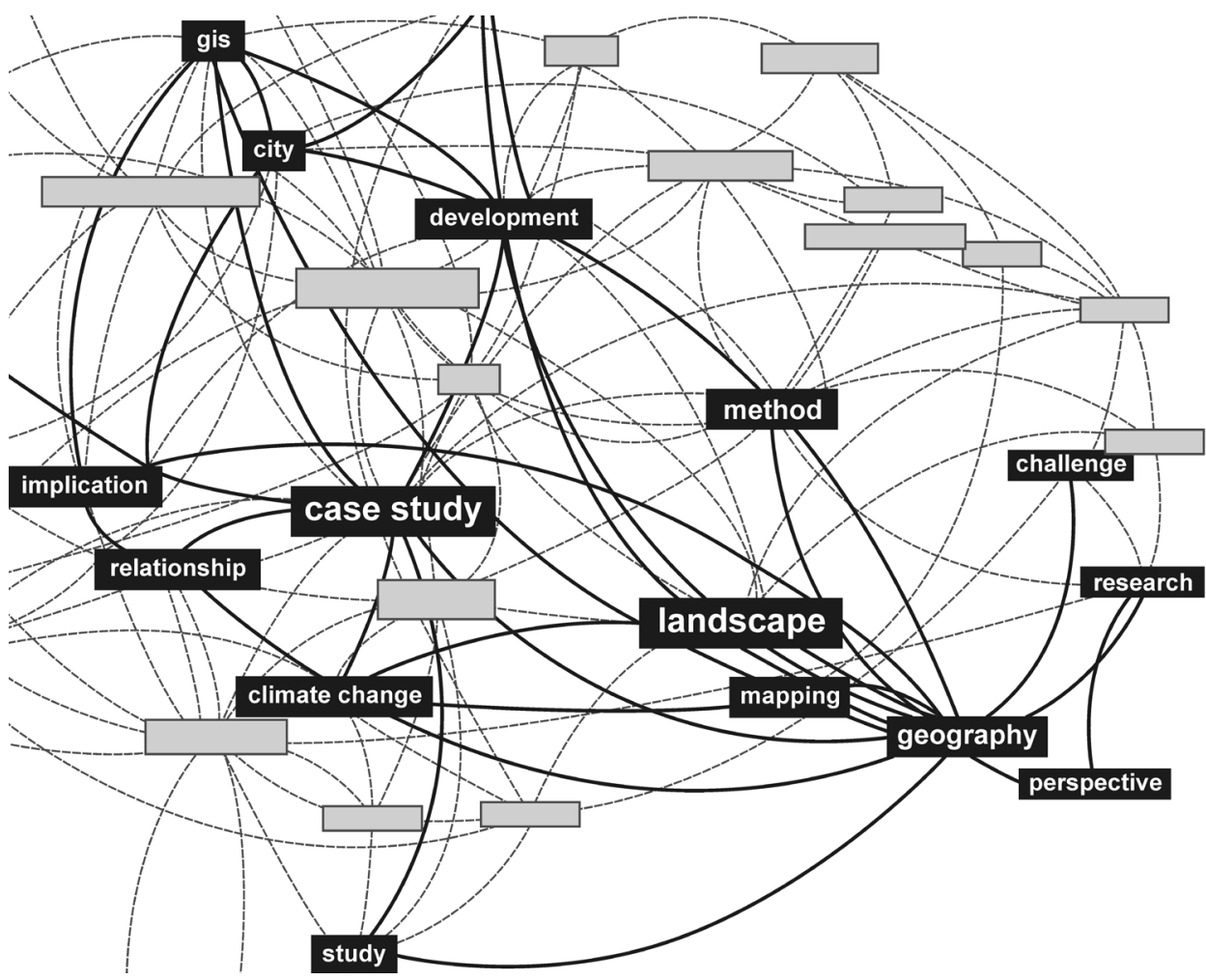

Ryc. 4. Najczęściej występujące i powiązane z terminem GIS pojęcia w analizie kontekstowej artykułów czasopism amerykańskich w zakresie geografii ogólnej (2014-2018) Źródło: opracowanie własne. 


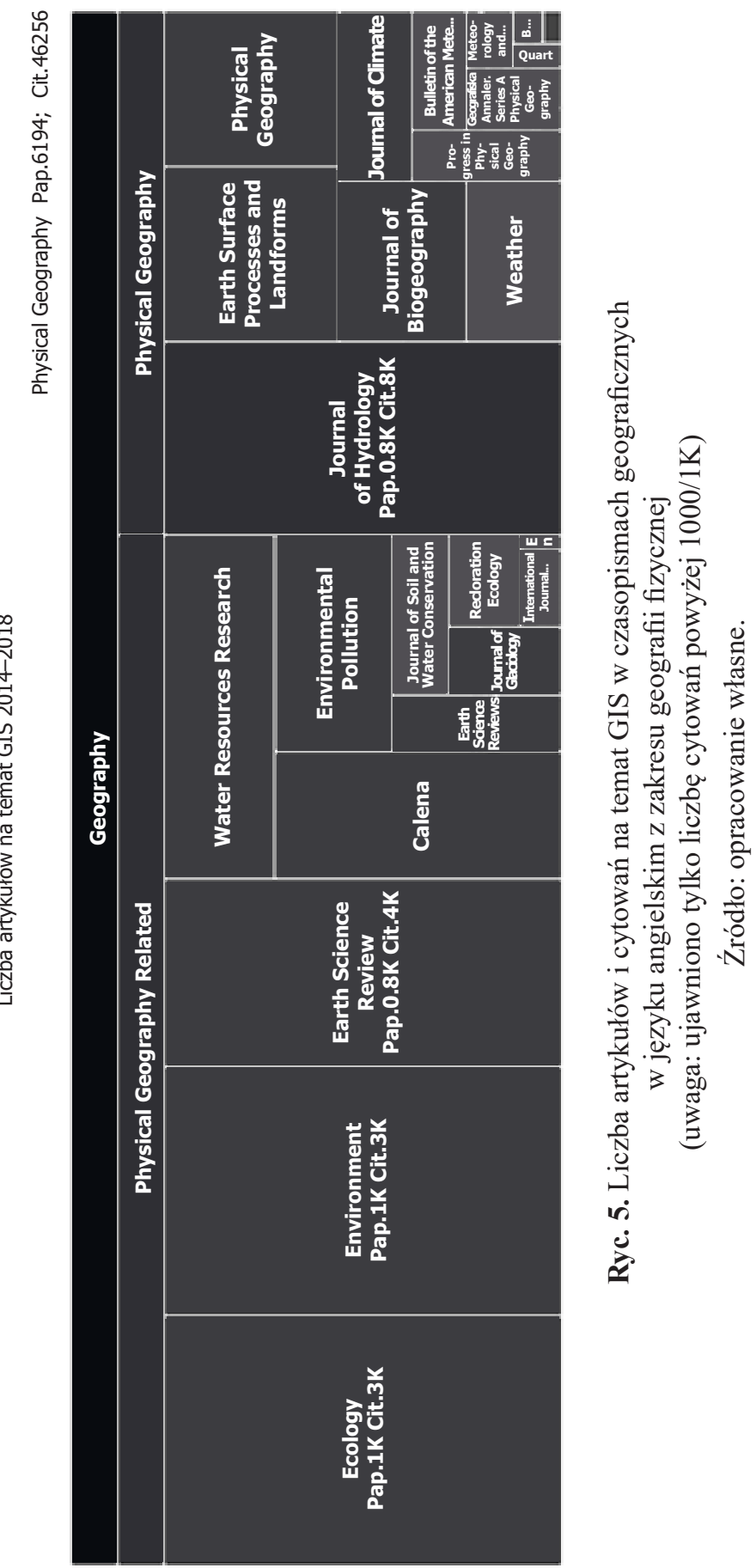



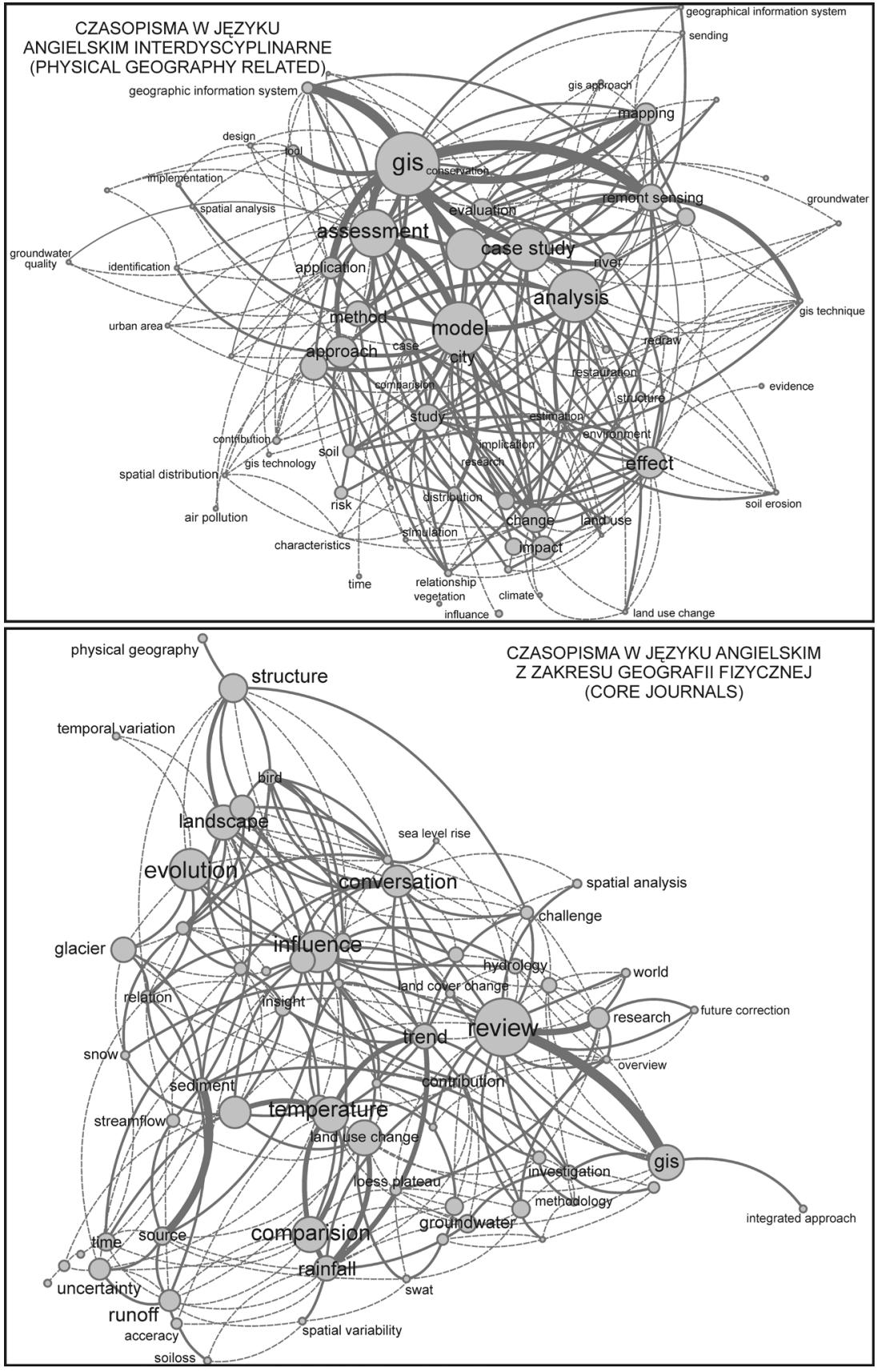

Ryc. 6. Najczęściej występujące i powiązane z terminem GIS pojęcia w analizie kontekstowej artykułów czasopism w zakresie geografii fizycznej (2014-2018) Źródło: opracowanie własne. 


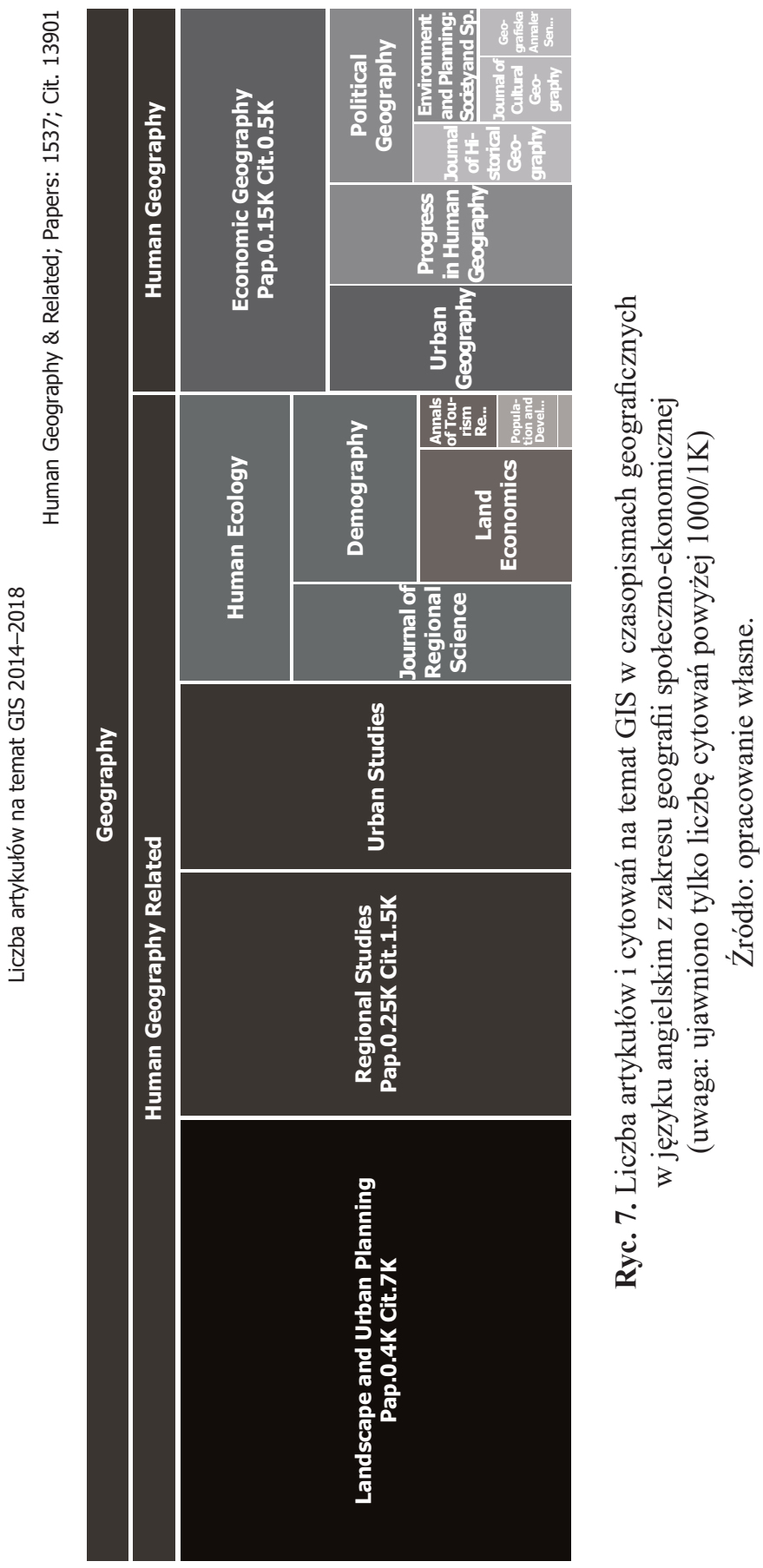




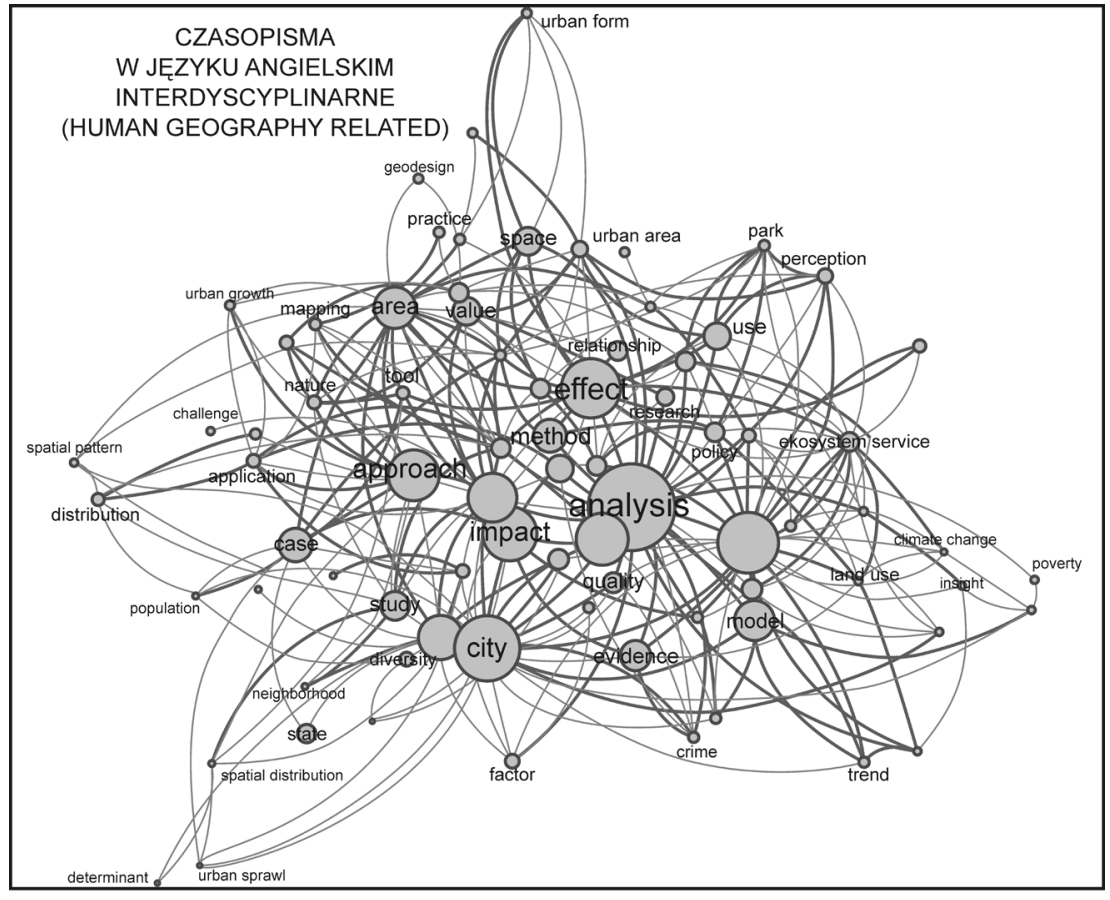

CZASOPISMA

residential space

W JĘZYKU ANGIELSKIM

Z ZAKRESU GEOGRAFII

housing

SPOŁECZNO-EKONOMICZNEJ

(CORE JOURNALS)

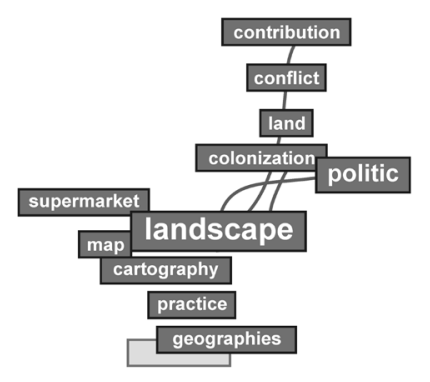

Ryc. 8. Najczęściej występujące i powiązane z terminem GIS pojęcia w analizie kontekstowej artykułów czasopism w zakresie geografii społeczno-ekonomicznej (2014-2018)

Źródło: opracowanie własne. 


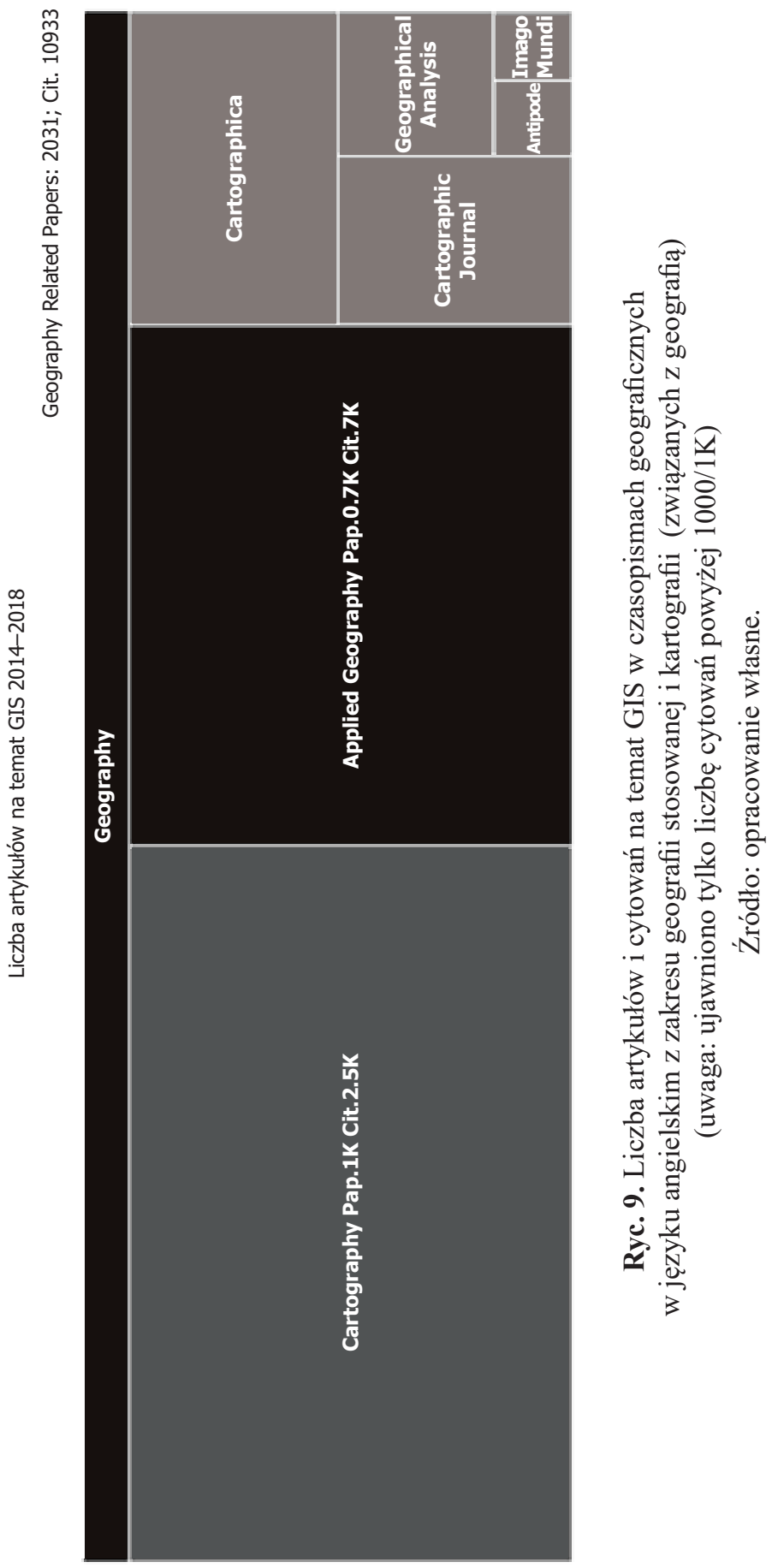




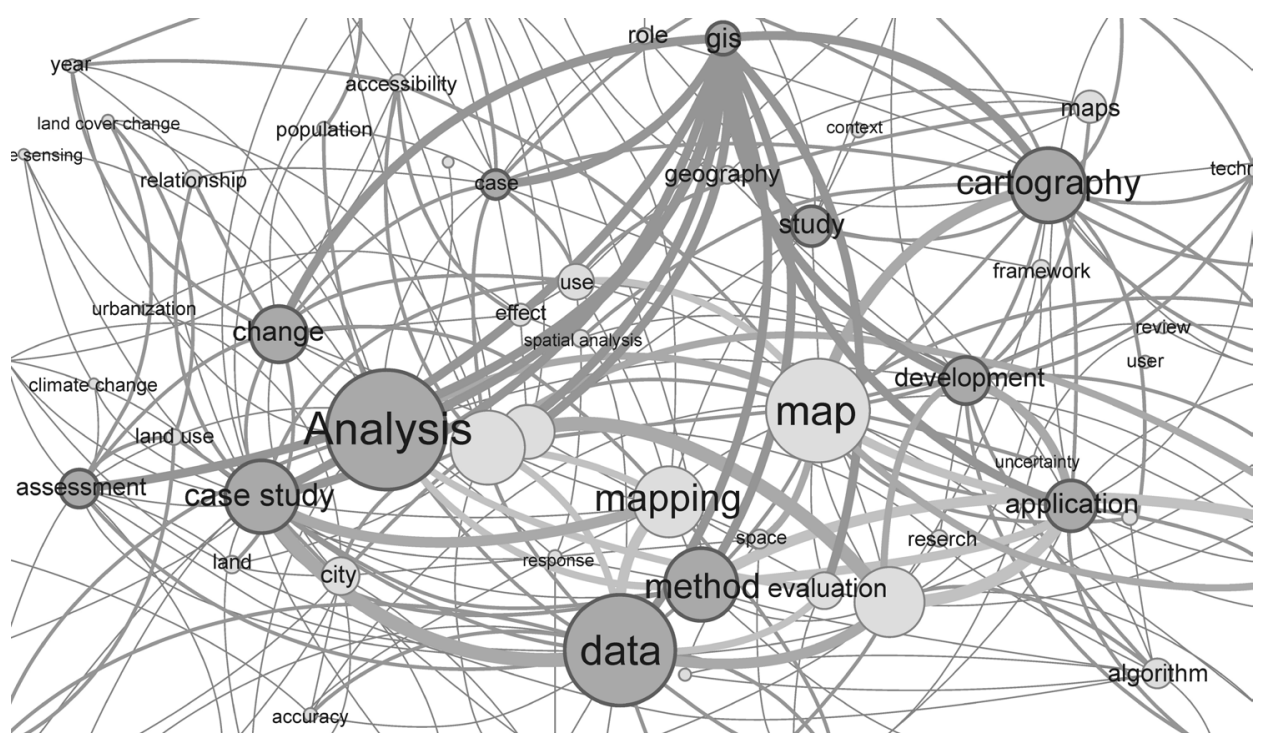

Ryc. 10. Najczęściej występujące i powiązane z terminem GIS pojęcia $\mathrm{w}$ analizie kontekstowej artykułów czasopism w języku angielskim w zakresie geografii stosowanej i kartografii (2014-2018) Źródło: opracowanie własne.

Dla dopełnienia obrazu poddano analizie (dla takiego samego okresu) także polskie czasopisma geograficzne publikujące artykuły w języku angielskim (ryc. 11, 12).

Uwidacznia się dominacja nauk o Ziemi i środowisku (geografii fizycznej) w zakresie zastosowań GIS. Jednak w geograficznym dyskursie naukowym najbardziej aktywne jawią się czasopisma geograficzne podejmujące tematykę interdyscyplinarną, metodologiczną lub z zakresu geografii stosowanej.

Ta obserwacja potwierdza także opinię na temat rozwoju geografii: „Zewnętrznie dyscyplina rozkwita, ale przede wszystkim na skutek zawirowań na peryferiach, odśrodkowo [...], ale głębszy wgląd pozwala skonstatować: obracając się i rozszerzając, peryferia się rozpadają, a centrum nie może utrzymać. Żadna inna innowacja technologiczna w historii ludzkości nie wpłynęła na praktykowanie geografii w tak głęboki sposób jak komputer. Drastycznie przekształciła ona zarówno geografię jako dyscyplinę akademicką, jak i geografię świata" (Sui, Morrill 2004). 

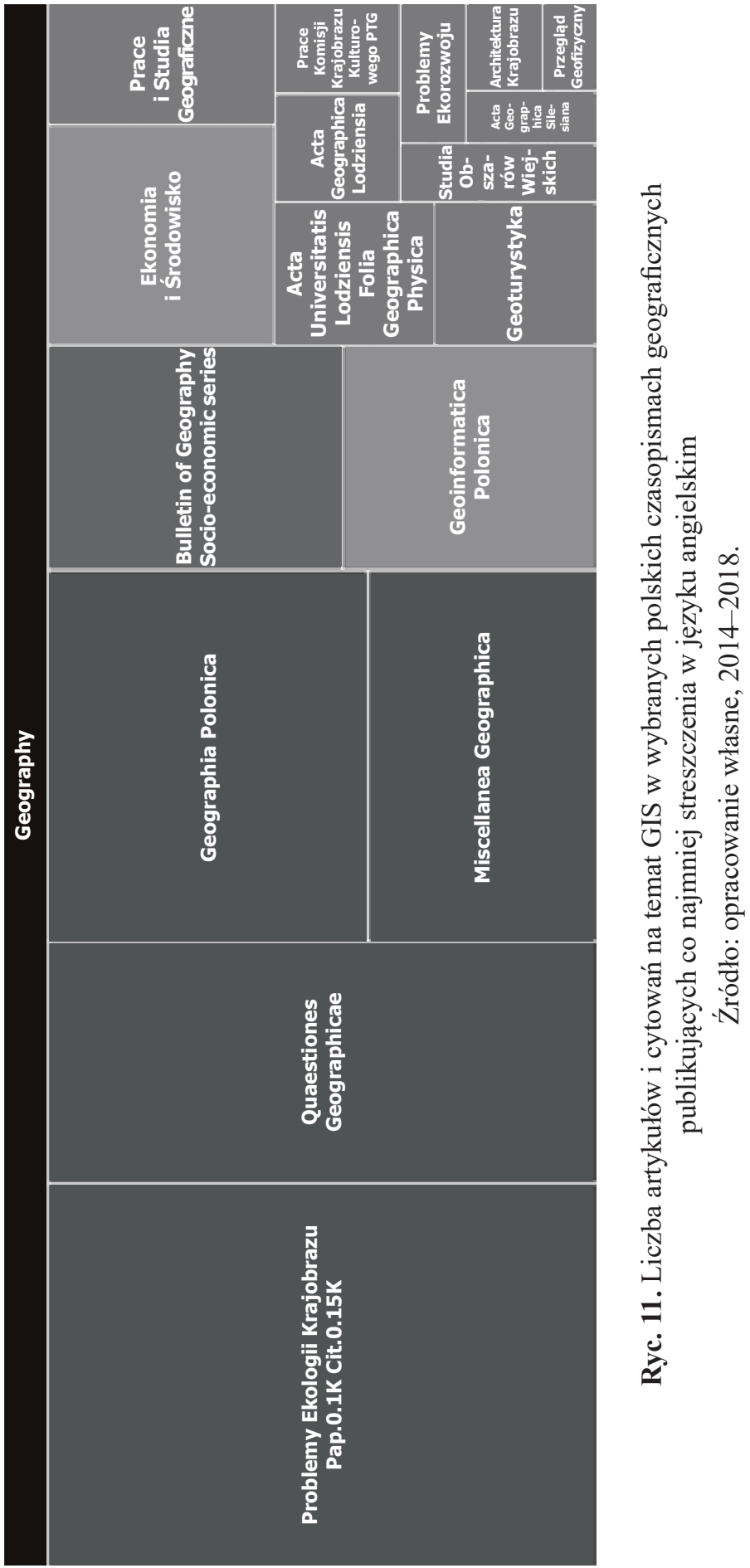


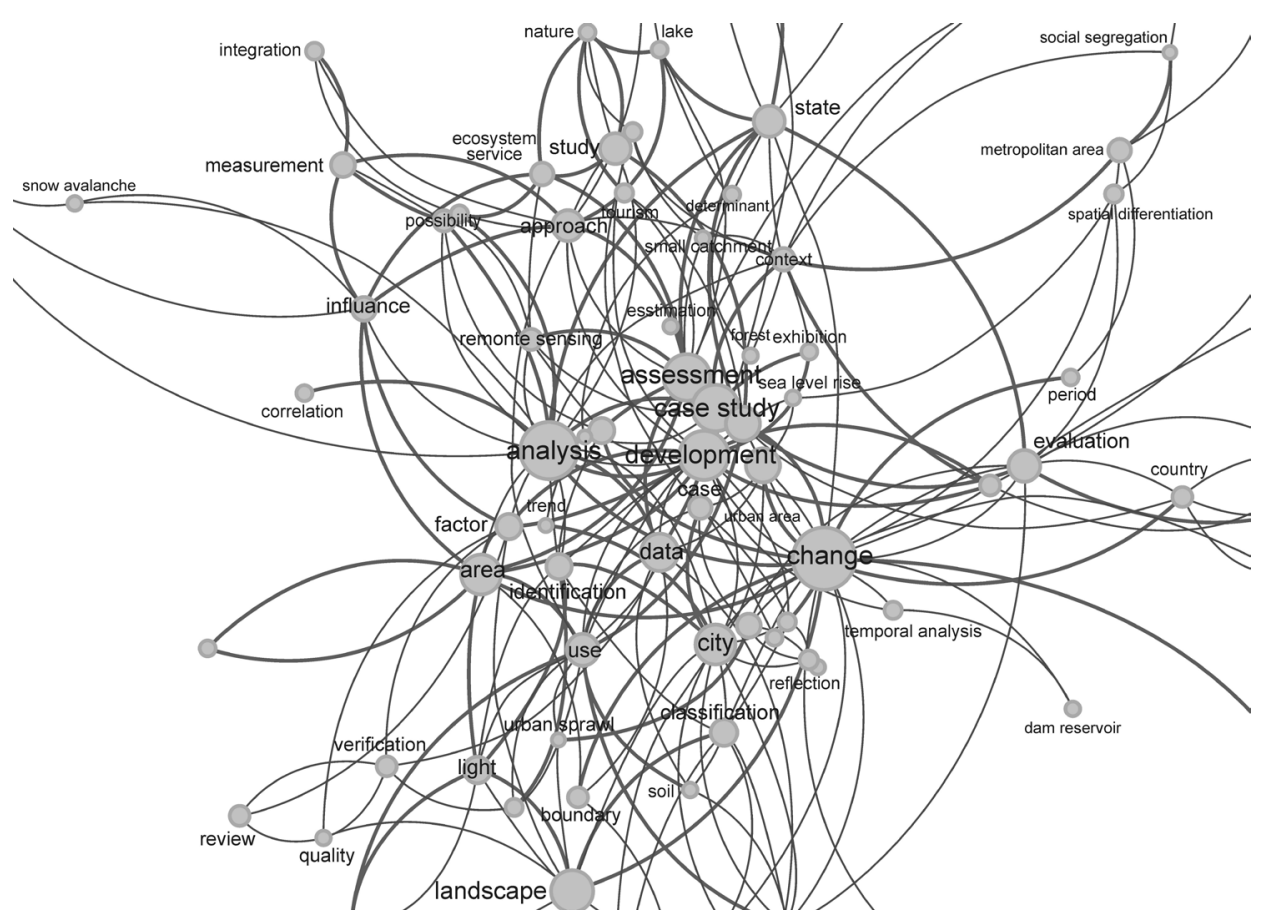

Ryc. 12. Najczęściej występujące i powiązane z terminem GIS pojęcia w analizie kontekstowej artykułów polskich czasopism geograficznych publikujących co najmniej streszczenia w języku angielskim (2014-2018)

Źródło: opracowanie własne.

\section{Wnioski}

Efektem wyodrębnienia się głównych nurtów GIS: aplikacyjnego i metodologicznego (GIScience) jest autonomizacja dyscypliny. Skutkiem praktycznym - pojawienie się coraz większej liczby odrębnych kierunków studiów, niezależnie od prowadzonych specjalizacji na studiach geograficznych i recepcja ich absolwentów w gospodarce. Nazywa się je różnie. W Polsce są to geoinformatyka, geomatyka i geoinformacja (w Lublinie, w Lodzi i w Poznaniu). W krajach angielskojęzycznych najczęściej GIScience, a w Europie i w Kanadzie geoinformatics, geomatics, a niekiedy także geospatial technologies.

Podobnie jak na świecie, GIS w geografii w Polsce rozwija się zasadniczo na peryferiach dyscypliny, na obszarach interdyscyplinarnych lub wytwarzając własne subdyscypliny (np. geomorfometria, symulacje dostępności transportowej). Wykorzystywany jest zasadniczo jako pomocnicza metoda, najczęściej do tworzenia zobrazowań kartograficznych w powiązaniu z metodami matematyki 
i statystyki. Algorytmizacja podejść badawczych w geografii postępuje bardzo wolno, a impulsy pochodzą spoza geografii. Wydaje się, że ważnym aspektem kształcenia geografów staje się wiedza o możliwościach pozyskiwania i źródłach danych geoprzestrzennych, użytecznych w nauce i praktyce gospodarczej badań geograficznych i z zakresu gospodarki przestrzennej. Należy odnotować jednak fakt, że głównym sponsorem tworzenia baz danych geoprzestrzennych i bibliotek aplikacji dostępowych do nich są instytucje państwowe, organizacje ponadnarodowe oraz, niedoceniany często, ruch open source.

W praktyce gospodarczej obserwuje się dwie przeciwstawne tendencje. Obserwowane jest przenikanie modelu grupowego działania wolontariuszy informacji geograficznej (np. VGI) nad projektami (internetowymi) do zasad funkcjonowania firm na rynku komercyjnym oraz do partycypacji społecznej w skali lokalnej - dzięki internetowi; są to emergentne zjawiska polegające na włączaniu zasad crowdsourcing $u \mathrm{w}$ gospodarce rynkowej, pozwalające firmom wspierać stowarzyszenia i fundacje typu open source, zyskując nowe rozwiązania, bazę wiedzy, wolontariuszy, ogromny wolumen danych i oczywiście potencjalnych klientów.

Próby komercjalizacji zebranych danych dokonują się także na bazie ruchu open source, m.in. pojawiają się nowe podmioty, które bazując na dokonaniach projektów otwartego oprogramowania i (lub) kolekcji zebranych danych, rozwijając je dalej, oferują (częściowo odpłatnie) znaczną wartość dodaną (przykład BoundlessGeo, mapy Google). Wolontariat danych geograficznych (VGI, crowdsourcing) ma jednak charakter wybiórczy. Badania naukowe i zebrane dane przestrzenne często mają charakter wycinkowy. Brakuje inicjatywy i koordynacji w celu ujednolicenia $\mathrm{i}$ wypracowania sposobu udostępniania danych przestrzennych pozyskanych w badaniach różnych, wycinkowych danych. Nie sprzyja temu także aktualna konkurencja w nauce (osób, ośrodków) oraz dyfuzja GIS w różnych subdyscyplinach powodująca fragmentację wiedzy. Istotnym, kluczowym czynnikiem dyfuzji GIS w edukacji społeczeństwa (geo)informacyjnego (obok dostępności oprogramowania open source GIS) jest właśnie dostępność tanich lub bezpłatnych danych przestrzennych.

\section{Literatura}

Ash J., Kitchin R., Leszczynski A., 2018, Digital turn, digital geographies?, „Progress in Human Geography", 42(1): 25-43.

Goodchild M.F., 2018, Geography and GISCIENCE, [Keynote lecture], http://igu2018. ulaval.ca.

Holt-Jensen A., 2018, Geography: history and concepts, Fifth Edition, SAGE Pub., Thousand Oaks, California.

Kitchin R., 2014, The data revolution: big data, open data, data infrastructures and their consequences, SAGE Publications, Los Angeles, California. 
Lazer D., Pentland A., Adamic L., Aral S., Barabasi A.-L., Brewer D., Christakis N., Contractor N., Fowler J., Gutmann M., Jebara T., King G., Macy M., Roy D., Van Alstyne M., 2009, SOCIAL SCIENCE: Computational Social Science, „Science”, 323(5915): 721-723.

McDowell L., 2008, Understanding diversity: the problem of/for theory, [w:] Theory and methods: critical essays in human geography, Contemporary foundations of space and place, Ashgate, Burlington, Vermont: 296-309.

Miller H.J., Goodchild M.F., 2015, Data-driven geography, „GeoJournal”, 80(4): 449-461.

Onsrud H., Kuhn W., 2016, ADVANCING GEOGRAPHIC INFORMATION SCIENCE: the past and next twenty years, S. 1.: GSDI Association Press.

Rogers R., 2015, Digital methods, The MIT Press, Cambridge, Massachusetts.

Rosenberg M., 2017, Geography Journals. Important Geographical Journals, https:// www.thoughtco.com/about-geography-journals-1435600 (dostęp: 7.04.2018).

Sui D., Morrill R., 2004, Computers and Geography: From Automated Geography to Digital Earth, [w:] Brunn S.D., Cutter S.L., Harrington J.W. (red.), Geography and Technology, Dordrecht: Springer Netherlands: 81-108; [online] http://link.springer. com/10.1007/978-1-4020-2353-8_5 (dostęp: 4.09.2018).

Unwin P.T.H., 2017, Reclaiming information and communication technologies for development, First edition, Oxford University Press, Oxford-New York, NY.

Werner P., 2013, Kreatorzy, gestorzy i internauci-od baz danych przestrzennych do map numerycznych $i$ wirtualnych globusów, Wizualne Bazy Danych, 36 (2): 239-250.

Yuan M., 2015, Frontiers of GIScience: Evolution, State-of-Art, and Future Pathways, https://www.researchgate.net/publication/269112940_Frontiers_of_GIScience Evolution_State-of-Art_and_Future_Pathways (dostęp: $\overline{3} .09 .2018$ ).

\title{
Akty prawne
}

Rozporzadzenie Ministra Nauki i Szkolnictwa Wyższego z dnia 20 września 2018 roku $w$ sprawie dziedzin nauki $i$ dyscyplin naukowych oraz dyscyplin artystycznych (Dz.U., 2018, poz. 1818).

\section{DOES GIS INCREASE POSITION OF GEOGRAPHICAL DISCIPLINES? IMPORTANCE OF GIS AND GISCIENCE FOR GEOGRAPHY}

\begin{abstract}
Geographers perceive information and communication technologies (ICT), including GIS software, as an element of inevitable transformations in geography. Some consider them to be ancillary to geography, some also note a digital turn that renews interest and links with areas such as computational social sciences and data-driven geography to gain a deeper insight into quantitative research, especially multi-resolution and multi-scale, on a time scale. Recently, the diversity of digital devices, platforms, applications and services is an inherent, normal and expected element of everyday life, and digital technologies are also a media standard for generating and analyzing knowledge in qualitative research. Progress, commercialization and popularization of geospatial technologies contribute to the development of spatial ontology and spatial epistemology.
\end{abstract}


Semantic analysis of articles published in the most important geographical scientific journals (2014-2018) proves that interdisciplinary, methodological or applied geography approaches are most active in geographical scientific discourse.

Keywords: ICT, GIS, geography, digital turn, geographical scientific discourse.

Prof. dr hab. Piotr Werner, prof. UW Katedra Geomatyki i Systemów Informacyjnych Wydział Geografii i Studiów Regionalnych Uniwersytet Warszawski e-mail: peter@uw.edu.pl 